\title{
MEMBANGUN UNJ SEBAGAI ORGANISASI BELAJAR YANG UNGGUL
}

Oleh: Khaerudin *)

\section{Abstrak}

Era informasi adalah era di mana segala sesuatu berkembang dan berubah dengan cepat. Suatu organisasi dituntut untuk terus mampu beradaptasi dan melakukan upaya peningkatan terusmenerus mengikuti irama perubahan lingkungan agar tetap bertahan (survive) dan mampu bersaing dengan organisasi lainnya. Sebagai suatu organisasi, Universitas Negeri Jakarta (UNJ) dituntut untuk mampu melakukan hal yang sama. Mengacu pada teori dan konsep organisasi belajar, makalah ini mengupas berbagai cara yang sebaiknya diterapkan oleh UNJ khususnya atau organisasi serupa lain pada umumnya agar tetap unggul di era global dewasa ini. Pembahasan meliputi konsep organisasi belajar dan cara yang sebaiknya ditempuh dari sisi (1) dinamika belajar yang dilakukan oleh anggota organisasi, baik sebagai individu, kelompok, maupun organisasi, (2) proses transformasi yang dilakukan menuju sebuah organisasi belajar yang diharapkan, (3) proses pemberdayaan sumber daya manusia yang dimiliki, baik dosen, karyawan, maupun mahasiswa, (4) proses manajemen pengetahuan sebagai roh dari sebuah organisasi belajar, dan (5) pemanfaatan teknologi untuk mendukung terjadinya berbagai perubahan untuk mengatasi dan mengantisipasi berbagai perubahan yang terjadi pada lingkungan yang akan mempengaruhi eksistensi UNJ.

Kata Kunci: organisasi belajar, disiplin, system thinking, team learning, mental model, shared vision, personal mastery, dinamika belajar, transformasi organisasi, pemberdayaan SDM, teknologi, knowledge management

\section{A. PENDAHULUAN}

Sebagai sebuah organisasi, Universitas Negeri Jakarta (UNJ) tidak bisa steril dari pengaruh lingkungan yang dinamis dan cepat berubah. UNJ harus peka terhadap perubahan, baik yang terjadi saat ini dan terutama perubahan-perubahan yang akan terjadi di masa yang akan datang. Layaknya sebagai sebuah organisme yang hidup di alam bebas dan lingkungan yang terus berubah, UNJ juga akan dihadapkan pada hukum alam. la akan dan telah lahir sebagai "bayi", kemudian tumbuh dan berkembang menjadi "anak-anak", "remaja”, "dewasa”, dan pada saatnya nanti akan menghadapi "kematian". Berkenaan dengan peristiwa "kematian" ini sangat bergantung kepada UNJ sendiri dalam kemampuannya melakukan adaptasi dan antisipasi terhadap berbagai perubahan yang terjadi pada lingkungannya. Bisa jadi peristiwa "kematian" itu akan terjadi dalam waktu satu tahun, sepuluh tahun, lima puluh tahun, atau seratus tahun ke depan. Atau bisa jadi sebelum "kematian" yang sesungguhnya terjadi sudah terlebih dahulu "mati suri", karena keberadaan dan kehidupannya tidak bisa lagi berbuat dan menghasilkan apa-apa.

*) Khaerudin, M.Pd., S3-TP PPs UNJ (dosen program studi teknologi pendidikan, FIP, UNJ) 
Secara lebih jelas Marquardt, mengingatkan terdapat empat kekuatan yang akan mendorong sebuah organisasi harus terus berubah (Marquardt, 1996), yang tentunya juga harus diantisipasi oleh UNJ, yaitu:

1. Perubahan dalam bidang sosial-ekonomi, dan ilmu pengetahuan, yang disebabkan oleh terjadinya globalisasi; berakibat semakin ketatnya tingkat persaingan dalam bidang barang dan jasa; terjadinya tekanan pada aspek lingkungan dan ekologi seperti pemanasan global (global warming); dan perkembangan dalam bidang ilmu pengetahuan dan teknologi yang sangat pesat.

2. Perubahan pada aspek lingkungan kerja, sebagai akibat dari tuntutan penerapan teknologi informasi dan komunikasi; perubahan dalam struktur organisasi; adanya tuntutan untuk meningkatkan efektivitas dan efesiensi organisasi; ledakan jumlah pekerja magang; dan keragaman dan mobilitas dunia kerja.

3. Perubahan harapan pelanggan berkenaan dengan aspek harga, mutu, inovasi dari barang dan jasa yang ditawarkan oleh organisasi, serta waktu dan pelayanan yang diberikan organisasi.

4. Perubahan harapan pekerja yang menuntut dimilikinya keahlian dan keterampilan yang lebih tinggi, diterapkannya berbagai peraturan kerja dalam organisasi, serta harapan-harapan yang menuntut manajer untuk terus memberi motivasi kepada karyawan dan memberi fasilitas yang diperlukan untuk melakukan pekerjaan.

Berbagai perubahan di atas akan menimbulkan masalah besar dan bahkan bisa berakibat pada kematian organisasi apabila tidak mampu diantisipasi dan dipecahkan dengan baik oleh organisasi (UNJ). Hal lain yang tidak kalah pentingnya adalah berbagai masalah tersebut harus dipecahkan dengan cara yang berbeda. Karena setiap masalah memiliki karakteristik yang berbeda dan menuntut pemecahan juga yang berbeda. Sebagaimana diungkapakan oleh Albert Einstein "No problem can be solved from the same consciousness that created it; we must learn to see the world anew" Untuk itu setiap organisasi termasuk
UNJ harus terus belajar mencari solusi atas setiap permasalahan yang diakibatkan oleh perubahan yang tidak dapat dihindarkan. Dengan kata lain, suatu organisasi seperti UNJ akan mampu bertahan menghadapi perubahan lingkungan apabila UNJ juga terus melakukan perubahan baik melalui proses belajar adaptif maupun generatif. Hal ini sejalan dengan pendapat Peter F. Drucker dalam "The Post Capitalist Society" bahwa keunggulan saat ini sangat ditentukan oleh "Proses Belajar". Siapa yang lebih cepat belajar dan mampu memanfaatkan keadaan, maka akan muncul sebagai pemenang (Yusuf, 2008).

\section{B. HAKIKAT ORGANISASI BELAJAR}

Organisasi adalah suatu wadah tempat berkumpulnya lebih dari satu orang yang memiliki tujuan yang sama, dan diikat oleh suatu kesepakatan bersama. Organisasi dibentuk untuk mencapai tujuan bersama secara efisien dan efektif, yang sekaligus menjadi prinsip suatu organisasi. Efisiensi dan efektivitas menjadi prinsip utama dalam sebuah organisasi, karena kita menghadapi berbagai keterbatasan sumber daya. Oleh karena itulah, salah satu yang menjadi tujuan seseorang masuk ke dalam suatu organisasi adalah agar upaya pencapaian tujuannya dapat dilakukan dengan efisien dan efektif. Sekalipun ukuran efisiensi dan efektivitas masing-masing individu bisa berbeda.

Agar sebuah organisasi dapat bertahan dan berkembang di tengah gelombang perubahan yang terjadi dalam lingkungannya, maka organisasi tersebut harus menjadi organisasi belajar. Terdapat sejumlah pendapat dan definisi tentang organisasi belajar. Peter Senge, misalnya, mendefinisikan organisasi belajar sebagai suatu organisasi di mana para anggota dari suatu organisasi secara terus menerus memperluas kemampuannya untuk terus berkeinginan belajar dan mengembangkan potensi diri (team learning) (Senge, 1990). Pedler dan Dixon di dalam Beardwell dan Holden (2001) mendefinisikan organisasi belajar sebagai organisasi yang memfasilitasikan pembelajaran bagi seluruh anggotanya dan mentransformasikan secara sadar dalam konteks organisasi (Yusuf, 2008). Sementara Marquardt mendefinisikan 
organisasi belajar sebagai suatu organisasi yang belajar secara kolektif dan bersemangat, dan terus menerus mentransformasikan dirinya pada pengumpulan, pengelolaan dan penggunaan pengetahuan yang lebih baik bagi keberhasilan perusahaan (Marquardt, 1996).

Dari berbagai pendapat di atas dapat disimpulkan bahwa organisasi belajar adalah suatu organisasi yang memfasilitasi dan menumbuhkan komitmen semua anggotanya untuk terus mengembangkan dirinya melalui kegiatan belajar.

Untuk menjadi organisasi belajar, Senge mengemukakan, suatu organisasi harus menerapkan lima disiplin belajar berikut, yaitu berpikir sistem (system thinking), model mental (mental models), penguasaan pribadi (personal mastery), visi bersama (share vision), dan belajar beregu (team learning). Sementara Marquardt mengemukakan suatu organisasi belajar akan terbangun dengan menerapkan lima subsistem yang saling berinteraksi dan saling mendukung menjadi sebuah sistem. Kelima subsistem tersebut, adalah subsistem orang, pengetahuan, organisasi, teknologi, dan subsistem belajar sebagai intinya (Marquardt, 1996).

\section{PROFILE UNJ SEBAGAI SEBUAH ORGANISASI}

Universitas Negeri Jakarta adalah nama yang digunakan untuk mengganti IKIP Jakarta yang mendapatkan perluasan mandat (wider mandate), dari perguruan tinggi yang memiliki tugas sebagai Lembaga Pendidikan Tenaga Kependidikan (LPTK) yang menghasilkan tenaga kependidikan menjadi perguruan tinggi yang juga menghasilkan tenaga non kependidikan. Dengan perluasan mandat ini maka sejak tahun 1998, IKIP Jakarta berubah nama menjadi Universitas Negeri Jakarta, dan sejak saat itu, UNJ mulai membuka program studi non kependidikan. Di samping itu, semua fakultas, kecuali Fakultas IImu Pendidikan (FIP), berubah nama dengan menghilangkan kata "Pendidikan" nya, seperti Fakultas Pendidikan Bahasa dan Seni berubah menjadi Fakultas Bahasa dan Seni, Fakultas Pendidikan Matematika IImu
Pengetahuan Alam menjadi Fakultas Matematika dan Ilmu Pengetahuan Alam.

Saat ini UNJ terdiri terdiri dari tujuh fakultas dan satu program pasca sarjana, dengan 72 program studi (kependidikan dan non kependidikan). UNJ dikelola dan dibina oleh 535 orang karyawan dan 953 orang dosen termasuk 37 orang profesor. Sementara jumlah mahasiswa yang dibina sekitar 19.857 orang.

Visi UNJ adalah "menghasilkan tenaga kependidikan yang bermutu tinggi untuk memenuhi kebutuhan sistem pendidikan nasional, mengembangkan ilmu pendidikan serta menghasilkan tenaga non-kependidikan dan mengembangkan ilmu non-kependidikan yang relevan. Lembaga ini dikembangkan dengan semangat kewirausahaan sebagai universitas yang religius, modern, efesien dan mampu bersaing dan bekerjasama dalam tataran global" (UNJ, 2002).

Sedangkan misi yang diemban adalah membina dan mengembangkan:

a. Ilmu, teknologi, dan seni yang dapat meningkatkan kualitas hidup manusia dan lingkungan.

b. Tenaga akademik dan/atau profesional yang bermutu, bertanggung jawab dan mandiri di bidang pendidikan dan nonkependidikan guna menghadapi berbagai tantangan di masa depan.

c. Berbagai bentuk pengabdian kepada masyarakat di bidang ilmu, teknologi, dan seni yang berdaya guna dan berhasil guna.

d. Budaya akademik yang kondusif bagi pemberdayaan semua potensi kemanusiaan yang optimal dan terintegrasi secara berkesinambungan.

e. Dirinya selaku universitas yang mampu menerapkan prinsip-prinsip enterpreneurship dalam kinerjanya secara berkesinambungan.

f. Budaya kewirausahaan dan kerjasama yang saling menguntungkan dengan berbagai lembaga di dalam maupun di luar negeri dalam melaksanakan Tridarma Perguruan Tinggi sebagai perwujudan dari kebersamaan hidup untuk membangun masa depan yang lebih baik. 
g. Kemitraan dalam rangka menyelenggarakan otonomi daerah (UNJ, 2002).

Di samping Visi dan Misi, UNJ juga memiliki Motto, yaitu "Building Future Leader" (mempersiapkan pemimpin masa depan) (UNJ, 2002).

Dilihat dari lokasi, posisi UNJ berada di kota Metropolitan Jakarta, yang merupakan satusatunya perguruan tinggi negeri. Namun di sekitarnya terdapat sejumlah perguruan tinggi swasta yang "bonafid" di samping tentunya ratusan perguruan tinggi swasta yang apa adanya.

\section{MEMBANGUN UNJ SEBAGAI ORGANISASI BELAJAR}

Mencermati berbagai perubahan lingkungan, baik yang berasal dari lingkungan internal maupun eksternal, tidak ada pilihan bagi UNJ, agar tetap eksis dan berkembang, untuk melakukan tranformasi diri menjadi organisasi belajar. Merujuk pada konsep organisasi belajar yang dikemukakan oleh Marquardt, maka untuk menjadi organisasi belajar yang unggul, UNJ harus membangun sebuah sistem yang utuh dan komprehensif, dengan cara mengembangkan (1) dinamika belajar yang dilakukan oleh anggota organisasi, baik sebagai individu, kelompok, maupun organisasi, (2) proses transformasi yang dilakukan menuju sebuah organisasi belajar yang diharapkan, (3) proses pemberdayaan sumber daya manusia yang dimiliki, baik dosen, karyawan, maupun mahasiswa, (4) proses manajemen pengetahuan sebagai roh dari sebuah organisasi belajar, dan (5) pemanfaatan teknologi untuk mendukung terjadinya berbagai perubahan untuk mengatasi dan mengantisipasi berbagai perubahan yang terjadi pada lingkungan yang akan mempengaruhi eksistensi UNJ.

\section{Membangun lingkungan belajar yang dinamis dengan melibatkan indvidu, kelompok, dan organisasi}

Belajar merupakan inti dari organisasi belajar. Tanpa belajar maka tidak terbangun suatu organisasi belajar. Karena itu penciptaan suasana belajar yang kondusif menjadi syarat mutlak untuk menjadi organisasi belajar. Oleh karena itu, iklim belajar yang dinamis dari sebuah organisasi seperti UNJ sangat bergantung pada proses belajar yang dilakukan oleh anggota organisasinya, baik secara individual, tim (group), maupun organisasi.

Seberapa besar dan intens anggota organisasi (stake holders) melakukan proses belajar akan berpengaruh terhadap dinamika belajar organisasi. Karena dinamika organisasi belajar akan terjadi hanya melalui individu yang belajar. Sekalipun belajar individu tidak menjamin terjadinya belajar organisasi, namun tanpa belajar individu tidak akan terjadi belajar organisasi, demikian dikatakan Peter Senge (Senge, 1990).

Salah satu upaya untuk menciptakan belajar yang dinamis dalam rangka membangun organisasi belajar adalah dengan memberi kesempatan belajar yang seluas-luasnya bagi setiap anggota organisasi (individu), seperti kesempatan belajar mengelola diri sendiri, belajar dari dan bersama teman kerja, menyediakan fasilitas akses internet yang memadai agar anggota individu dapat belajar melalui bantuan komputer, berbagi (sharing) pengalaman kerja sehari-hari antaranggota organisai, memberi tugas khusus untuk mengerjakan sebuah proyek, dan mengembangkan wawasan pribadi, baik melalui kegiatan pendidikan formal maupun non formal dan informal.

Iklim belajar yang dinamis akan terwujud apabila proses belajar bukan hanya dilakukan individu tetapi juga oleh tim dan organisasi. Belajar tim memiliki peran yang sangat penting pada saat organisasi menghadapi permasalahan yang kompleks yang sulit dipecahkan secara individual; dan pada saat memerlukan pemikiran yang variatif dan komprehensif. Belajar tim yang sangat solid memungkinkan ditemukannya pemikiran kolektif dan komunikasi yang efektif dan juga kemampuan untuk bekerja secara kreatif dan konstruktif sebagai sebuah sistem. 
Sejumlah indikator yang harus dicapai oleh UNJ untuk menjadi organisasi belajar yang dinamis, adalah adanya dukungan yang optimal dari top manajer, para pimpinan universitas, fakultas, dan unit pendukung, untuk tercapainya visi organisasi belajar; adanya iklim yang mendukung dan kesadaran dari semua stake holders akan pentingnya belajar; UNJ sebagai sebuah organisasi terus belajar, bukan hanya dari kesuksesankesuksesan yang telah diraihnya, tetapi juga belajar dari kegagalan-kegagalan yang dialaminya di masa lalu; terbangunnya komunikasi yang efektif antara anggota organisasi pada berbagai level, dikuasainya kemampuan dan keterampilan belajar adaptif, antisipatori, deutro, dan belajar aksi.

Secara praktis, Marquardt mengemukakan terdapat sepuluh strategi untuk membangun subsistem belajar yang dinamis yaitu: ${ }^{1}$

1) Mengembangkan program tindakan belajar melalui organisasi.

2) Meningkatkan kemampuan individu untuk belajar bagaimana belajar.

3) mengembangkan disiplin dialog dalam organisasi.

4) menciptakan rencana pengembangan karir untuk karyawan.

5) membangun program cash pengembangan diri.

6) membangun keterampilan belajar beregu.

7) mendorong dan mempraktekan berpikir sistem.

8) menggunakan scanning dan skenario rencana untuk mengatisipasi belajar.

9) mendorong/memperluas pola pikir (mindsets) dan belajar perbedaan, multikultural dan global.

10) merubah pola mental relatif untuk belajar (Marquardt, 1996).

\section{Melakukan transformasi organisasi}

Kegiatan trasformasi organisasi dilakukan sebagai upaya untuk mereformasi, merestrukturisasi, memfokuskan kembali peran dan fungsi UNJ sebagai LPTK yang memiliki mandat yang diperluas (wider mandate). Upaya ini harus terus didorong agar proses transformasi UNJ sebagai organisasi yang selama ini belum belajar menjadi organisasi belajar.

Upaya yang harus dilakukan UNJ untuk melakukan transformasi organisasi adalah:

a. Membangun visi bersama

Visi adalah image, gambaran, wujud yang ingin dicapai oleh seseorang atau sebuah organisasi. Visi adalah arah kemana seseorang atau organisasi akan melangkah. Oleh karena itu, dalam konteks organisasi, visi organisasi harus dipahami oleh semua anggota organisasi. Visi organisasi jangan hanya dimiliki oleh pimpinan organisasi. Visi organisasi harus benar-benar menjadi impian semua anggota organisasi. Dengan kata lain visi organisasi harus menjadi visi bersama.

Untuk mewujudkan visi bersama, proses penyusunan visi harus melibatkan semua unsur atau stake holders (mahasiswa, dosen, karyawan, dan para pemakai lulusan) melalui suatu proses dialog. Untuk itu perlu dibentuk gugus tugas (taskforce) yang bertugas membangun dialog dengan stake holders, sehingga dapat diserap harapan dan "impian" dari masingmasing unsur tentang UNJ seperti apa yang ingin diwujudkan di masa yang akan datang. Dengan langkah ini diharapkan akan terumuskan visi bersama yang mengakomodir harapan semua pihak, dan benarbenar akan menjadi arah dan impian bersama. Visi yang dirumuskan harus benar-benar khas yang menjadi penciri UNJ, sehingga dapat dibedakan dengan perguruan tinggi yang sejenis sebagai LPTK yang mendapat perluasan mandat.

b. Membuat indikator pencapaian visi Agar proses pencapaian visi dapat dikontrol dan diukur maka sebuah visi harus dijabarkan menjadi sejumlah 
indikator pencapaian. Karena itu sebuah visi yang baik harus mencantumkan target waktu pencapaiannya, dan menggambarkan ruang lingkup (area) visi tersebut akan diwujudkan. Target waktu pencapaian menjadi penting untuk menentukan tahap-tahap pencapaian yang lebih sistematis dan sistemik. Sekalipun dalam perjalanan visi tersebut bisa saja harus berubah karena tuntutan perubahan lingkungan. Demikian juga dengan ruang lingkup (area) pencapaian diperlukan untuk dapat dianalisis kekuatan, kelemahan, tantangan, dan peluang (SWOT) organisasi (UNJ) dalam membangun kerjasama dengan rekan kerja (partnership), dan dalam menghadapi persaingan dengan para pesaingnya di area yang telah ditetapkan.

c. Menilai dan menentukan titik berangkat mencapai visi

Dalam upaya mewujudkan visi organisasi, UNJ harus memahami betul posisi awal tentang kondisi riil yang dimilikinya. Oleh karena itu, proses analisis SWOT yang obyektif dan komprehensif menjadi sangat menentukan. Dengan pemahaman kondisi awal pada saat akan melangkah dan tahu dengan jelas arah dan tujuan (visi) yang akan dicapai, maka memudahkan UNJ dalam mengatur strategi pencapaiannya.

Merujuk pada pendapat Marquardt, ${ }^{12}$ terdapat sepuluh strategi utama untuk melakukan transformasi organisasi menjadi organisasi belajar (Marquardt, 1996), yang dapat diadopsi oleh UNJ, yaitu:

1) menangani berbagai konferensi dan penelitian untuk mengembangkan visi organisasi belajar;

2) membangun dukungan dari para top manajer untuk menjadi organisasi belajar ;

3) menciptakan iklim akademik lingkungan UNJ untuk melakukan belajar berkelanjutan;
4) merekayasa kembali kebijakan dan struktur organisasi UNJ yang memungkinkan anggotanya terus belajar;

5) menerapkan prinsip reward and punishment kepada anggota yang terus belajar baik secara individual maupun beregu;

6) membuat belajar menjadi bagian dari seluruh kebijakan dan prosedur organisasi UNJ;

7) membangun pusat keunggulan yang menjadikan UNJ sebagai organisasi belajar;

8) menggunakan pengukuran finansial dan nonfinansial sebagai sebuah aktivitas belajar;

9) menciptakan waktu, tempat, dan lingkungan fisik untuk belajar; dan

10) membuat belajar yang disengaja pada setiap waktu dan di semua lokasi;

\section{Memberdayakan Sumber Daya Manusia}

Sumber daya manusia adalah pelaku utama dalam sebuah organisasi. Tanpa sumber daya manusia yang memadai, sebuah organisasi akan menghadapi permasalahan besar yang akan berdampak pada terancamnya eksistensi organisasi. Oleh karena itu, sebuah organisasi harus menjadi organisasi belajar yang ditandai oleh setiap sumber daya manusianya terus belajar; belajar dalam menghadapi dan memecahkan setiap tantangan dan permasalahan yang dihadapi oleh organisasinya, bahkan belajar untuk menciptakan berbagai inovasi untuk mengembangkan organisasinya.

Dalam konteks organisasi UNJ, sumber daya manusia yang harus terus diberdayakan agar memberi kontribusi yang positif bagi terbentuknya organisasi belajar adalah para dosen, karyawan, dan para pimpinan, baik tingkat universitas, fakultas, lembaga, dan unit pelaksana teknis. Sebagai anggota organisasi, 3 mereka memiliki tugas dan tanggung jawab yang sama untuk mengembangkan UNJ sebagai organisasi belajar melalui proses belajar yang tiada henti. 
Untuk mendorong setiap anggota organisasi (UNJ) menjadi pemelajar sepanjang hayat, maka UNJ harus memberi kebebasan, kekuatan, dan semangat untuk terus belajar; memaksimalkan pemberian delegasi otorisasi dan tanggung jawabnya; melibatkan mereka dalam merencanakan dan mengembangkan organisasi; serta menjaga keseimbangan kebutuhan organisasi dan kebutuhan individual (Organization equilibrium), mengembangkan budaya kerja dalam tim, dan tidak kalah pentingnya adalah memberdayakan pegawai agar mampu bekerja tanpa arahan langsung dari manajer, atau melaksanakan "continuous improvement" berdasarkan visi bersama.

Pemberdayaan sumber daya manusia yang menjadi anggota organisasi UNJ juga diarahkan agar mereka memiliki komitmen yang tinggi untuk memajukan UNJ, melepaskan sentimen individu dan mengutamakan kepentingan UNJ, dan berusaha meleburkan diri ke dalam pemikiran kolektif untuk mencapai tingkat penetrasi dan inovasi yang maksimal. Membangun keterbukaan antaranggota organisasi juga menjadi prasyarat untuk terjadinya organisasi belajar yang unggul. Melalui keterbukaan diharapkan setiap anggota organisasi menjadi lebih "wellinformed", sehingga dalam setiap pengambilan keputusan didasarkan pada data dan fakta yang akurat.

Agar sumber daya manusia yang ada dalam organisasi UNJ memberi kontribusi dalam mendorong UNJ menjadi organisasi belajar yang unggul, dapat dilakukan dengan cara:

1. mengembangkan kebijakan organisasi yang memberi hadiah kepada para anggota organisasi yang terus belajar;

2. menciptakan situasi dan kondisi yang memungkinkan terjadinya pengelolaan-diri tim kerja;

3. memberi kesempatan kepada karyawan dan dosen untuk terus belajar dan berkarya;
4. mendorong para pimpinan universitas, fakultas, lembaga dan unit pelaksana teknis lainnya untuk menjadi model pemelajar sepanjang hayat;

5. mengundang pemimpin untuk lomba proses belajar dan proyek;

6. menyeimbangkan belajar dan kebutuhan perkembangan individu dan organisasi;

7. mendorong dan meningkatkan partisipasi pelanggan (mahasiswa, sekolah, depdiknas, dII) dalam organisasi belajar;

8. menyediakan kesempatan belajar bagi masyarakat;

9. membangun kerjasama belajar jangka panjang dengan vendor dan suplier; adn

10. memaksimalkan belajar melalui aliansi (alliances) dan kerjasama (join ventures) dengan stakeholders (Marquardt, 1996).

\section{Mengelola pengetahuan}

Untuk menjadikan UNJ sebagai organisasi belajar yang unggul, UNJ harus memperhatikan keberadaan dan pengembangan subsistem pengetahuan sebagai basis kerja semua anggota organisasinya. UNJ harus menyadari bahwa pengetahuan merupakan subsistem yang paling vital setelah subsistem belajar. Bahkan kedua sistem ini akan selalu terkait. Pengetahuan yang menjadi basis kerja harus terus dikembangkan, baik melalui proses belajar adaptif maupun proses belajar generatif.

Keberadaan pengetahuan dalam sebuah organisasi belajar ibarat makanan yang menjadi nutrisi yang dibutuhkan untuk menumbuhkembangkan tubuh manusia. Semua komponen organisasi memerlukan pengetahuan. Staf administrasi memerlukan pengetahuan yang sangat memadai untuk dapat melayani stakeholders dengan baik dan memuaskan. Apalagi para dosen, yang bertugas memfasilitasi para mahasiswa mengembangkan dirinya untuk menjadi "sosok" yang diinginkannya. 
Untuk menjadi organisasi belajar yang unggul, UNJ harus mampu mengelola pengetahuan secara sistematis dan sistemik. UNJ harus mengembangkan suatu sistem agar mampu memperoleh, menciptakan, menyimpan, dan membagi (sharing) pengetahuan dengan baik, baik dilakukan oleh anggota organisasi secara mandiri atau dalam bentuk team learning maupun melalui kerjasama dengan organisasi di luar UNJ.

Proses memperoleh pengetahuan dapat dilakukan secara internal maupun eksternal. Sebagai organisasi belajar, UNJ dapat memperoleh pengetahuan dari anggota organisasinya (secara internal), baik dosen, staf dan pimpinan, bahkan para mahasiswa sendiri. Upaya ini dapat dilakukan dengan cara memahami dan menyelami pengetahuan anggota organisasinya, belajar dari pengalaman melalui proses refleksi dan diskusi, dan juga menerapkan proses perubahan yang berkelanjutan.

Sedangkan proses memperoleh pengetahuan dari pihak eksternal dapat dilakukan melalui:

- Bekerjasama dari organisasi lain.

- Menghadiri konferensi.

- Merekrut konsultan.

- Membaca materi cetak seperti koran, surat elektronik, dan jurnal.

- Menonton televisi, video, dan film.

- Memperhatikan trend ekonomi, sosial, dan teknologi.

- Mengumpulkan data dari konsumen, pesaing, dan sumber lain.

- Merekrut pegawai baru.

- Bekerjasama dengan organisasi lain, membuat aliansi, dan membentuk usaha bersama (Marquardt, 1996).

Proses menciptakan pengetahuan dapat dilakukan secara adaptif dan juga secara generatif. Pengetahuan yang bersifat adaptif diciptakan dalam upaya mereaksi dan mengatasi permasalahan yang sedang dihadapi. Berbagai perkembangan dalam bidang sosial, ekonomi, politik, dan teknologi sering menimbulkan masalah yang harus segera diatasi dengan pengetahuan baru yang sebelumnya belum dimiliki organisasi. Sedangkan pengetahuan yang bersifat generatif adalah pengetahuan yang secara sengaja dikembangkan secara proaktif untuk mengantisipasi berbagai perkembangan dan perubahan lingkungan, baik secara internal maupun eksternal.

UNJ sebagai sebuah organisasi belajar harus mampu melakukan keduanya, menciptakan pengetahuan yang bersifat adaptif dan generatif. Melalui bidang penelitian sebagai salah satu dari kegiatan tridarma perguruan tingginya, UNJ harus mampu mendorong setiap anggota organisasi menciptakan pengetahuan. Hasil dari proses ini bukan sekedar untuk mempertahankan eksistensi organisasi, tetapi diharapkan akan mendorong perubahan dalam berbagai bidang dalam masyarakat.

Lembaga Penelitian memiliki peran yang strategis untuk memfasilitasi proses penciptaan pengetahuan yang akan dilakukan oleh anggota organisasi UNJ. Baik dosen maupun mahasiswa, atau mungkin juga staf administrasi diberi kesempatan yang luas untuk melakukan berbagai penelitian untuk mengembangkan dan menciptakan pengetahuan, baik yang bersifat adaptif maupun generatif.

Ada sejumlah aktivitas yang dapat dilakukan UNJ untuk dapat menciptakan pengetahuan, diantaranya melalui belajar dengan tindakan (action learning), pemecahan masalah secara sistematis (systematic problem solving), eksperimen, belajar dari pengalaman masa lalu (learning form past experiences). Dua kegiatan pertama bersifat adaptif, karena dilakukan untuk mengatasi masalah yang dihadapi, sedangkan dua kegiatan terakhir dilakukan dalam rangka mengantisipasi perubahan dan dalam upaya perluasan dan peningkatan kemampuan UNJ sebagai organisai belajar. 
Permasalahan lain yang tidak kalah pentingnya dalam mengelola pengetahuan sebagai basis kerja dan pengembangan organisasi adalah bagaimana UNJ sebagai organisai belajar mampu menyimpan pengetahuan yang dimilikinya dan dengan mudah diakses bila diperlukan. Permasalahan ini sebenarnya terkait dengan masalah manajemen sistem informasi. Sehubungan dengan ini Marquardt mengingatkan bahwa pengetahuan seharusnya disimpan dengan memperhatikan hal-hal berikut: ${ }^{15}$

- Tersusun dan tersimpan dengan baik sehingga sistem bisa menemukan dan mengirimkan informasi dengan cepat dan benar.

- Dibagi menjadi beberapa kategori seperti fakta, kebijakan, atau prosedur

- Tersusun sehingga informasi bisa dikirimkan dengan jelas dan cara yang singkat kepada pengguna.

- Bersifat akurat, tepat waktu, dan tersedia bagi setiap orang yang membutuhkan (Marquardt, 1996).

Di samping itu, proses manajemen pengetahuan juga harus memperhatikan latar belakang anggota organisasi (dosen, staf, mahasiswa, atau stake holders lainnya) sebagai pengguna. Ini penting mengingat masing-masing pengguna memiliki karakteristik yang berbeda, seperti kebutuhannya, tujuan pekerjaannya, keahliannya, manfaat informasi dan lokasi para anggota organisasi mengakses dan memanfaatkan pengetahuan tersebut.

Untuk kepentingan manajemen pengetahuan yang memadai, UNJ harus mengembangkan suatu sistem informasi yang berbasis TIK, yang dikelola secara profesional. Dalam kaitan ini optimalisasi peran dan fungsi Pusat Komputer (Puskom) dan Pusat Pengembangan Teknologi Informasi (PPTI) menjadi suatu keniscayaan. Demikian juga dengan semua Biro Administrasi yang ada, khususnya Biro Administrasi Pengembangan Sistem Informasi
(BAPSI) harus didorong untuk mampu mengelola pengetahuan dengan menggunakan basis data yang dapat diandalkan.

Proses penyebaran/pengiriman pengetahuan merupakan salah satu proses yang mempengaruhi kualitas manajemen pengetahuan dalam sebuah organisasi belajar. Dalam sebuah organisasi belajar diperlukan suatu sistem penyebaran dan pengiriman pengetahuan yang cepat dan akurat kepada seluruh bagian atau anggota organisasi. Bagi UNJ, tuntutan ini harus disikapi dengan mengembangkan suatu mekanisme yang memungkinkan semua sivitas akademika dapat memperoleh pengetahuan yang berkembang dengan cepat dan akurat.

Mekanisme yang dikembangkan baik dengan memanfaatkan teknologi informasi dan komunikasi maupun secara manual. Hal yang penting di sini adalah kejelasan mekanisme tersebut sehingga semua anggota organisasi memahami bagaimana mereka dapat mengirim dan menerima pesan dengan baik.

Beberapa cara yang dapat ditempuh oleh organisasi dalam pengiriman pengetahuan, yaitu:

1. Dalam bentuk komuniksi tertulis perseorangan, seperti dalam bentuk memo, laporan, surat, papan pengumuman terbuka.

2. Melalui pelatihan, seperti konsultasi internal, kursus formal, dan pelatihan kerja.

3. Mengadakan konferensi internal.

4. Melakukan briefing.

5. Menggunakan publikasi internal, seperti video, teks, audio.

6. Melaksanakan tur (Marquardt, 1996).

Mengingat peran manajemen pengetahuan yang sangat vital dalam sebuah organisasi seperti UNJ agar dapat menjadi organisasi belajar yang unggul, maka UNJ harus dapat mengimplementasikannya dengan merujuk pada sepuluh strategi utama 
untuk mengelola pengetahuan yang dikemukakan oleh Marquardt, yaitu:

1. menciptakan harapan yang membuat setiap orang bertanggung jawab untuk mengumpulkan dan mentransfer pengetahuan;

2. secara sistematis mengambil (capture) pengetahuan luar yang relevan untuk organisasi;

3. mengorganisir even-even belajar dengan organisasi untuk mengambil dan berbagi pengetahuan;

4. mengembangkan cara berpikir dan belajar yang kreatif dan generatif;

5. mendorong dan memperkuat inovasi dan penemuan;

6. melatih staf dalam menyimpan dan mengambil pengetahuan;

7. mendorong tim gabungan dan rotasi tugas untuk memaksimalkan transfer pengetahuan lintas batas;

8. mengembangkan suatu basis pengetahuan sekitar nilai-nilai dan kebutuhan belajar organisasi;

9. menciptakan mekanisme untuk belajar mengumpulkan dan menyimpan ; dan

10. mentransfer belajar kelas ke pekerjaan (Marquardt, 1996).

\section{Memanfaatkan teknologi}

Perkembangan teknologi informasi dan komunikasi (TIK) terjadi sangat pesat. Dengan potensinya yang sangat besar, TIK akan dan telah membawa dampak yang luas terhadap berbagai aspek kehidupan. Di satu sisi, keberadaan dan pemanfaatan TKI ini membawa manfaat yang besar, membuat hidup dan kehidupan manusia semakin mudah, namun di sisi lain, keberadaanya tidak sedikit menimbulkan masalah, terutama bagi mereka yang tidak mau dan tidak mampu mengikuti perkembangannya.

UNJ sebagai organisasi yang akan menjadi organisasi belajar yang unggul, harus mampu mengambil sikap yang bijak dalam menghadapi perkembangan TIK ini. Untuk menjadi sebuah organisasi belajar yang unggul, UNJ harus mampu memanfaatkan TIK ini dengan tepat untuk memfasilitasi semua anggota organisasinya terus belajar. Hal ini harus dipertimbangkan, karena apabila suatu organisasi memutuskan untuk menggunakan TIK, akan berdampak pada sejumlah hal, di antaranya: mengubah cara menyelesaikan masalah, akan terjadi penggabungan sejumlah fungsi organisasi, mengubah iklim kompetisi, menghadirkan peluangpeluang strategi baru, menuntut perubahan dasar, dan mendorong transformasi (Marquardt, 1996).

Salah satu bentuk adopsi TIK yang dapat mendorong UNJ menjadi organisasi belajar, adalah dengan memanfaatkan TIK sebagai sarana untuk melaksanakan Belajar Berbasis Teknologi (TechnologyBased Learning). Dengan mengadopsi model belajar berbasis teknologi akan mendorong seluruh anggota organisasi untuk melek teknologi (technology literacy), dan terus belajar sesuai dengan kapasitas dan tugasnya masing-masing.

Para dosen akan dituntut untuk terus belajar mengembangkan bahan ajar, berbagai strategi pembelajaran, dan sistem evaluasi yang berbasis TIK. Para mahasiswa dituntut untuk mampu menggunakan dan memanfaatkan perangkat TIK sebagai media dan sekaligus sebagai sumber belajarnya.

Dengan mengadopsi TIK sebagai salah satu sub sistem dalam organisasi belajar, akan menuntut para karyawan untuk terus belajar bagaimana memanfaatkan dan mengembangkan manajemen sistem informasi (administrasinya) yang berbasis TIK; Tentu saja tidak ketinggalan para pimpinan fakultas, unit, dan universitas juga harus terus belajar dengan memanfaatkan TIK, untuk mendapatkan data dan informasi yang akurat sebagai dasar dalam pengambilan keputusannya dan sekaligus untuk mensosialisasi kebijakan yang diambilnya.

Implikasi dari mengadopsi TIK dalam sistem organisasi adalah diperlukan pengembangan perangkat keras (hardware), perangkat lunak (software) dan perangkat manusianya (brainware). 
Di sadari betul bahwa untuk penyediaan berbagai perangkat ini, akan diperlukan sumber dana yang tidak sedikit.

Di samping penyediaan sejumlah komputer dengan jumlah yang cukup, pada aspek perangkat keras ini, perlu juga dikembangkan jaringan yang baik dan memadai yang dapat menghubungkan antara "Pusat TIK" dengan berbagai unit dan fakultas. Pembangunan jaringan dapat dilakukan dengan menggunakan sistem kabel atau tanpa kabel (nircable).

Pengembangan sarana dan prasarana "Pusat TIK" juga harus menjadi perhatian serius. Demikian juga dengan penyediaan dan pengembangan sumber daya manusianya yang profesional dalam TIK harus mendapat perhatian yang lebih. Evaluasi dan restrukturisasi Pusat Komputer (Puskom) dan Pusat Pengembangan Teknologi Informasi (PPTI) juga perlu dilakukan agar dapat bekerja secara optimal dan profesional, sehingga mampu melayani semua staf dan civitas akademika UNJ, melakukan proses belajar secara berkelanjutan.

Untuk mewujudkan UNJ sebagai organisasi belajar yang ditandai dengan pemanfaatan teknologi dalam keseluruhan subsistem organisasinya, diperlukan suatu strategi yang tepat agar proses penerapan TIK menjadi lebih efektif dan efisien. Marquadt mengemukakan terdapat sepuluh strategi utama yang dapat dilakukan untuk menerapkan teknologi dalam sebuah organisasi, yaitu:

1) mendorong dan menyediakan fasilitas bagi semua staf untuk dapat terkoneksi dengan internet;

2) mengembangkan multimedia, pusat belajar berbasis teknologi;

3) membuat atau memperluas pembelajaran video interaktif;

4) menggunakan teknologi untuk memperoleh pengetahuan dan ideide dari orang dalam dan luar organisasi;

5) memperoleh dan mengembangkan kompetensi untuk belajar teknologi sendiri atau dengan kelompok;

6) menginstal sistem dukungan kinerja elektronik;

7) merencanakan dan mengembangkan sistem belajar segera (just-in-time);

8) membangun kapabilitas dan teknologi perangkat kursus internal;

9) mengembangkan kesadaran dan penghargaan pada teknologi sebagai alat yang memiliki kekuatan untuk belajar mengembangkan organisasi; dan

10) meningkatkan tanggung jawab manajemen teknologi dan staf sumber daya manusia (Marquardt, 1996).

\section{E. KESIMPULAN DAN SARAN}

\section{Kesimpulan}

Setiap organisasi, termasuk UNJ, akan selalu berhadapan dengan berbagai perubahan, baik yang berasal dari dalam organisasi (internal) maupun berasal dari luar organisasi (eksternal). Setiap perubahan selalu memunculkan masalah yang harus dapat diatasi dengan baik oleh organisasi. Apabila ia tidak mampu mengatasinya, maka "kematian" organisasi akan segera tiba.

Untuk mengatasi berbagai permasalahan yang muncul, dan sekaligus agar mampu mempertahankan eksistensinya, maka setiap organisasi harus mentransformasi diri menjadi organisasi belajar. Dengan menjadi organisasi belajar, maka setiap anggota organisasi akan terus menerus belajar mengembangkan kapabilitasnya, baik secara individual, tim, maupun organisasi; baik melalui belajar adaptif maupun generatif. Melalui belajar maka organisasi akan mampu memanaj pengetahuan yang dimilikinya untuk mengatasi setiap permasalahan yang dihadapi dan mengantisipasi perkembangan di masa yang akan datang.

\section{Saran}

Dalam membangun sebuah organisasi belajar yang unggul, UNJ harus mampu mengembangkan dinamika belajar yang dilakukan oleh sivitas akademika, melakukan transformasi organisasi, memberdayakan sumber daya manusia yang dimiliki, baik 
dosen, karyawan, maupun mahasiswa, mengembangkan manajemen pengetahuan yang baik, dan memanfaatkan teknologi untuk mendukung terjadinya berbagai perubahan untuk mengatasi dan mengantisipasi berbagai perubahan yang terjadi pada lingkungan yang akan mempengaruhi eksistensi UNJ.

\section{DAFTAR PUSTAKA}

Marquardt, Michael J., Building the Learning Organization, A Systems Approach to Quantum Improvement and Global Success. New York: McGraw-Hill, 1996
Reiser, Robert A., Jaohn V. Dempsey. Trends and Issues in Instructional Design and Technology, Second Edition. New Jersey: Pearson Prentice Hall, 2007

Senge, Peter M., The Fifth Discipline: The Art and Practice of The Learning Organization. 1990 Senge, Peter M., School Thar Learn, A Fifth Discipline. New York: Doubleday Dell Publishing Group, Inc. 2000

Universitas Negeri Jakarta, Pedoman Kegiatan Akademik tahun 2002, p. 3

Yusuf, Adie E., http://teknologikinerja.wordpress. com/2008/05/06/organisasi-belajar/ didownload Kamis, 11 Desember 2008 